\title{
Menilai Teknik Penyebatian Kemahiran Berfikir sebagai Satu Alternatif untuk Meningkatkan Kemahiran Berfikir dan Memahami Mata Pelajaran

\author{
Badariah Hashima ${ }^{*}$, Nurulhuda Abd Rahman ${ }^{b}$, Razak Abd. Samad Yahya ${ }^{b}$ \\ aJabatan Sains, Institut Pendidikan Guru Kampus Ipoh, 31150 Hulu Kinta, Perak, Malaysia \\ ${ }^{b}$ Fakulti Sains dan Matematik, Universiti Pendidikan Sultan Idris, 35900 Tanjung Malim, Malaysia
}

*Corresponding author: badariah@ipip.edu.my

\begin{abstract}
This research is intended to evaluate the use of the infusing thinking skills technique in teaching Form Four Physics in the topic of heat through the students' achievements in the Critical Heat Test. The research involves the types of thinking skills, which are the parts-whole relationships, comparing and contrasting, and conceptualization. Teachers need to choose the most suitable type of thinking skills for the topic that will be taught in order to attain the learning outcome required. Additionally the infusing thinking skills technique, along with thinking skills, also contain the training of mind of habits in the behavior of students and metacognition whereby students will reflect on the thinking skills process during the teaching and learning activity. The use of thinking maps according to the type of thinking as mentioned, can help students think in step by step sequence. The methodology of the study is quasiexperimental and shows the disproportionate test design of the pre- and post-test groups. Research samples are purposive sampling, containing 30 people for each treatment group and control group. Two schools in Kinta Utara were involved in this study. Results show that there are significant differences in test-t, that is the score increment (critical heat posttest score-pretest score) of the treatment group as compared to the control group. It is found that the infusing thinking skills technique is suitable to enhance thinking skills and the students understanding of the heat topic. This technique is an alternative for teachers to apply various types of thinking skills required in Physics to train thinking skills to the students. Through conceptualization skills, students will be able to find Physics concepts from what they already know and from their daily experiences by using conceptual maps.
\end{abstract}

Keywords: Infusing thinking skills technique; the parts-whole relationships; comparing and contrasting; conceptualization

\begin{abstract}
Abstrak
Kajian ini bertujuan untuk menilai penggunakan teknik penyebatian kemahiran berfikir dalam pengajaran Fizik Tingkatan Empat dalam tajuk haba melalui pencapaian murid dalam Ujian Haba Kritis. Kajian ini melibatkan jenis pemikiran iaitu hubungan sebahagian keseluruhan, membanding dan membeza, dan mengkonsepsikan. Guru hendaklah memilih jenis kemahiran berfikir yang sesuai dengan tajuk yang diajar dalam usaha untuk mencapai hasil pembelajaran yang dikehendaki. Di samping itu, teknik penyebatian kemahiran berfikir, selain kemahian berfikir juga mengandungi penerapan tabiat minda dalam tingkahlaku murid-murid dan metakognisi dimana murid membuat refleksi proses kemahiran berfikir yang telah berlaku semasa pengajaran dan pembelajaran. Penggunaan peta pemikiran mengikut jenis pemikiran yang telah dinyatakan, membantu murid-murid berfikir mengikut urutan langkah demi langkah. Metodologi kajian ialah kuasi eksperimental mengambil reka bentuk ujian pra-pasca kumpulan-kumpulan tidak seimbang. Sampel kajian adalah jenis sampel bertujuan, mengandungi seramai 30 orang untuk setiap kumpulan rawatan dan kumpulan kawalan. Dua buah sekolah di Kinta Utara terlibat dalam kajian ini. Keputusan menunjukkan terdapat perbezaan yang signifikan dalam ujian-t iaitu peningkatan skor (skor pascaujian-skor praujian) haba kritis kumpulan rawatan berbanding kumpulan kawalan. Didapati teknik penyebatian kemahiran berfikir adalah sesuai untuk meningkatkan kemahiran berfikir dan kefahaman murid dalam tajuk haba. Teknik ini adalah satu alternatif bagi guru mengaplikasikan pelbagai jenis kemahiran berfikir dalam kandungan matapelajaran Fizik untuk melatih kemahiran berfikir kepada murid-murid sekolah. Melalui kemahiran mengkonsepsikan membolehkan murid menemukan sendiri sesuatu konsep fizik melalui pengetahuan sedia ada dan pengalaman dalam kehidupan seharian melalui menggunakan peta mengkonsepsikan.
\end{abstract}

Kata kunci: Teknik penyebatian kemahiran berfikir; hubungan sebahagian keseluruhan; membanding dan membeza; mengkonsepsikan

(C) 2017 Penerbit UTM Press. All rights reserved

\subsection{PENGENAlan}

The Partnership for $21^{\text {st }}$ Century Skills iaitu sebuah organisasi di Amerika yang mendahului dalam memfokuskan aspek penyebatian kemahiran berfikir ke dalam pendidikan abad 21 kini, dimana antara elemen tersebut ialah pemikiran kritikal (21 ${ }^{\text {st }}$ century skills, 2008). Program pendidikan di Lithuania (sebuah negeri di Eropah) juga mementingkan pemikiran kritikal (Indrasiene, Suboc \& Penkauskiene, 2012). Malaysia telah merangka satu Pelan Pembangunan Pendidikan Malaysia mulai 2013 hingga 2025, dimana dalam gelombang 1 (2013-2015) antara tujuan transformasi pendidikan adalah untuk mereka bentuk semula soalan peperiksaan supaya boleh menjurus kepada soalan kemahiran berfikir aras tinggi (Kementerian Pendidikan Malaysia, 2015). Dalam Pelan Pembangunan Pendidikan Malaysia terdapatnya aspirasi murid secara individu, diantaranya ialah setiap murid perlu menguasai pelbagai kemahiran kognitif termasuk penaakulan dan pemikiran kritis, kreatif serta inovatif. Dapat disimpulkan bahawa, Abad 21 mempamerkan kepentingan kemahiran 
berfikir untuk dikuasai oleh setiap individu di seluruh pelusuk alam, sehubungan dengan itu, pendidikan formal menggalas tugas berat ini untuk memastikan setiap pelajar mempunyai kebolehan dalam kemahiran berfikir.

Menurut laporan Kajian Keperluan (needs analysis) oleh Perunding Kestrel Education (UK) dan $21^{\text {st }}$ Century Schools (USA) pada 2 November 2011 telah menunjukkan kemahiran berfikir aras tinggi dalam kalangan guru dan murid di Malaysia adalah rendah. Seterusnya, rentetan daripada laporan Trends in International Mathematics and Science Study ( TIMSS) 2011 dan Laporan Kajian Keperluan, maka Program i-Think diperkenalkan bermula pada 2012 bertujuan untuk menjadikan kemahiran berfikir sebagai satu budaya kepada murid dan juga guru di sekolah (Membudayakan, 2012).

Keutamaan kemahiran berfikir bukan perkara baru dalam sistem pendidikan di Malaysia, sebagai contoh, Sukatan Pelajaran Kurikulum Bersepadu Sekolah Menengah, Fizik (2001) menekankan penguasaan kemahiran berfikir seperti yang tertera dalam objektif kurikulum Fizik. Ini bukan suatu masalah kerana mengajar kemahiran berfikir aras tinggi adalah sesuai untuk semua murid (Venville \& Oliver, 2015). Objektif pembelajaran Fizik (Sukatan pelajaran, 2001) diantaranya ialah untuk membentuk pelajar mempunyai kemahiran berfikir. Dinyatakan juga bahawa kemahiran berfikir terbahagi kepada kemahiran berfikir kritikal dan kemahiran berfikir kreatif. Kemahiran berfikir kritikal terdiri daripada menciri, membanding dan membeza, membentuk kumpulan dan pengkelasan, membuat urutan, menyusun mengikut keutamaan, menganalisis, mengesan kecondongan, menilai dan membuat kesimpulan. Kemahiran berfikir kreatif pula terdiri daripada cetusan idea, membuat hubungan, membuat inferensi, meramal, membuat generalisasi, visualiti, mensintesis, membuat hipotesis, membuat analogi dan mencipta.

Guru sememangnya memberi penekanan dalam kandungan fizik yang diajar, walaubagaimanapun guru juga perlu mengetahui tentang murid dan pembelajaran mereka iaitu apakah pengetahuan sedia ada murid apabila mereka mula belajar dan bagaimana mereka berinteraksi dan memberi maklumbalas kepada suasana serta kandungan pembelajaran yang guru sediakan (Redish, 1994). Didapati penyelesaian masalah secara tradisional seperti melakukan banyak soalan latihan mempunyai kesan yang terhad terhadap pemahaman dalam konsep fizik murid (Kim \& Pak, 2002). Sarimah \& Shaharom (2008) mendapati bahawa tahap penguasaan kemahiran berfikir kritis murid Sains Tingkatan Empat di Daerah Kulai dalam negeri Johor keseluruhannya pada tahap sederhana. Kajian ini menyarankan semoga proses pengajaran dan pembelajaran perlu memberikan penekanan kepada proses penerapan kemahiran berfikir agar murid dapat meningkatkan tahap penguasaan kemahiran berfikir kritis mereka.

\subsection{SOROTAN LITERATUR}

Pemikiran kritikal meningkatkan perkembangan akademik; semakin banyak integrasikan/penyebatian ke dalam kandungan pengajaran maka semakin banyak pelajar menganalisa konsep yang dipelajari (Swartz \& Parks, 1994). Kemahiran berfikir boleh disebatikan dalam pelajaran merentas pelbagai disiplin menggunakan penyoalan yang mendalam dan penilaian terhadap data dan pelbagai sumbar (McCollister \& Sayler, 2010). Pembelajaran kolaboratif menaikkan perkembangan pemikiran kritikal pelajar berbanding secara individu melalui kaedah perbincangan, penjelasan idea dan penilaian idea oleh orang lain (Gokhale, 1995). Pembelajaran berasaskan masalah (PBL) berjaya untuk meningkatkan kemahiran berfikir logik pelajar (Yaman, 2005).

Tabiat minda (Costa \& Kallick, 2008) bererti seseorang mempunyai kecenderungan ke arah berkelakuan bijak apabila berhadapan dengan sesuatu masalah dimana penyelesaiannya tidak diketahui dengan mudah atau serta merta. Juga, ciri-ciri perlakuan tabiat minda yang tertentu akan ditunjukkan apabila mereka mempamirkan kebijaksanaan mereka semasa menyelesaikan sebarang masalah. Juga menurut Costa dan Kallick, tabiat minda terdiri daripada dua komponen iaitu, (i) Ia dapat dipamirkan melalui tingkahlaku yang tertentu dan pelbagai (ii) Ia menjadi tabiat dalam diri seseorang serta mempamirkannya apabila terlibat dalam sesuatu situasi yang sesuai.

Metakognisi merujuk kepada pemikiran mengenai pemikiran dan kognitif seseorang (Flavell, 1979). Dunlosky \& Metcalfe (2009) menyatakan metakognisi terbahagi kepada tiga aspek iaitu metakognisi pengetahuan, metakognisi pemantauan dan metakognisi pengawalan. Metakognisi pengetahuan ialah pengetahuan seperti fakta, kepercayaan dan peristiwa-peristiwa mengenai kognitif dan boleh dinyatakan secara verbal (dapat dipanggil dari memori jangka panjang). Metakognisi pemantauan merujuk kepada menilai atau mentaksir aktiviti kognitif yang sedang berlaku. Metakognisi pengawalan ialah mengatur aktiviti kognitif yang sedang berjalan sama ada untuk menghentikannya, meneruskannya atau menukarnya kepada yang lain di pertengahan jalan. Metakognisi hendaklah diajar kepada murid untuk memajukan pembelajaran mereka (Cook, Kennedy \& McGuire, 2013).

Kajian mendapati, kesedaran metakognitif dan penyelesaian masalah mempunyai hubungan yang signifikan, oleh itu beliau mencadangkan pengajaran kemahiran metakognisi perlu diutamakan untuk meningkatkan kemahiran penyelesaikan masalah pelajar (Yildirim \& Ersozlu, 2013). Pelajar didapati lebih melibatkan diri dengan kandungan kursus apabila aktiviti melibatkan metakognisi dilaksanakan (Sandall, Mamo, Speth \& Kettler, 2014). Pengajaran Sains yang berkesan bukan hanya meningkatkan pembelajaran tetapi juga membantu murid membangunkan kemahiran metakognitif mereka, malah didapati pelajar yang mempunyai pengaturan kendiri terhadap pembelajarannya mempunyai kemahiran metakognisi (Schraw, Crippen \& Hartley, 2006).

\section{Teknik Penyebatian Strategi Berfikir}

Teknik penyebatian kemahiran berfikir dalam kajian ini berasaskan kepada Swartz, Costa, Beyer, Reagan \& Kallick (2008). Jenis pemikiran yang termasuk dalam kajian ini ialah hubungan sebahagian keseluruhan; membanding dan membeza yang berperanan untuk menganalisis idea dan maklumat; dan mengkonsepsikan untuk pemahaman yang mendalam (Swartz \& McGuinness, 2014). Teknik penyebatian kemahiran berfikir terdiri daripada peringkat pengenalan iaitu mengaitkan strategi berfikir dalam pengalaman harian murid secara eksplisit dan memperkenalkan kemahiran tabiat minda juga secara eksplisit. Seterusnya ialah peringkat aktiviti iaitu latihan terbimbing. Murid diberikan bahan rangsangan yang dipanggil lembaran aktviti ataupun maklumat yang sesuai diperolehi daripada rencana atau buku teks; dan peta pemikiran seperti hubungan sebahagian keseluruhan, Rajah 1; membanding dan membeza, Rajah 2; mengkonsepsikan, Rajah 3. Peta pemikiran merupakan satu pengurusan grafik bersifat dinamik secara kognitif bermaksud satu lakaran yang digunakan untuk membantu dan mengurus cara berfikir dengan lebih tersusun yang mengandungi kiu dan bantu ingat dalam bentuk visual, soalan dan pernyataan dalam menunjukkan arah pergerakkan minda dalam mengaplikasikan kemahiran berfikir tertentu (Nurulhuda \& Md Nasir, 2013). Maklumat yang terdapat pada rencana akan dipindahkan kepada peta pemikiran hubungan sebahagian keseluruhan; 
membanding dan membeza; dan mengkonsepsikan. Teknik penyebatian kemahiran berfikir selain mengaplikasikan kemahiran berfikir dalam penguasaan kandungan pembelajaran, juga menerapkan kemahiran tabiat minda dan metakognisi.

Strategi berfikir mengkonsepsikan diambil dari Kemahiran berfikir (2002), ia mengandungi enam buah pernyataan yang dipanggil langkah mengkonsepsikan. Seterusnya, saya transformasikan langkah mengkonsepsikan kepada soalan-soalan strategi mengkonsepsikan dan ditransformasi pula kepada peta mengkonsepsikan sebagai alat pemikiran untuk murid melakukan mengkonsepsikan. Dalam melakukan mengkonsepsikan, lembaran aktiviti mengandungi maklumat penceritaan suatu situasi yang terdapat satu konsep fizik yang bakal ditemui oleh pelajar. Maklumat pada lembaran aktiviti dipindahkan kepada peta pemikiran mengkonsepsikan secara tertib iaitu langkah demi langkah sehingga selesai dan akhirnya diperolehi satu konsep fizik yang terdapat pada lembaran aktiviti tersebut.

Teknik penyebatian kemahiran berfikir mempunyai langkah-langkah yang eksplisit dan jelas dalam melakukan setiap jenis kemahiran berfikir. Langkah-langkah kemahiran berfikir tersebut dibuat dalam bentuk peta pemikiran. Seseorang guru yang hendak mengajar menggunakan Teknik Penyebatian Kemahiran Berfikir perlu menyediakan lembaran aktiviti yang mengandungi maklumat-maklumat yang perlu diisi ke dalam peta pemikiran yang dipilih. Dalam kajian ini, maklumat tersebut adalah stuasi dalam kehidupan harian yang berkaitan dengan kandungan dalam tajuk haba Fizik Tingkatan Empat. Dalam erti kata lain, murid belajar Fizik menggunakan peta pemikiran yang sesuai dengan proses berfikir yang terlibat merujuk kepada hasil pembelajaran yang hendak dicapai. Guru perlu memilih apakah jenis pemikiran yang sesuai digunakan untuk menyampaikan isi pelajaran tersebut.

PETA HUBUNGAN SEBAHAGIAN KESELURUHAN

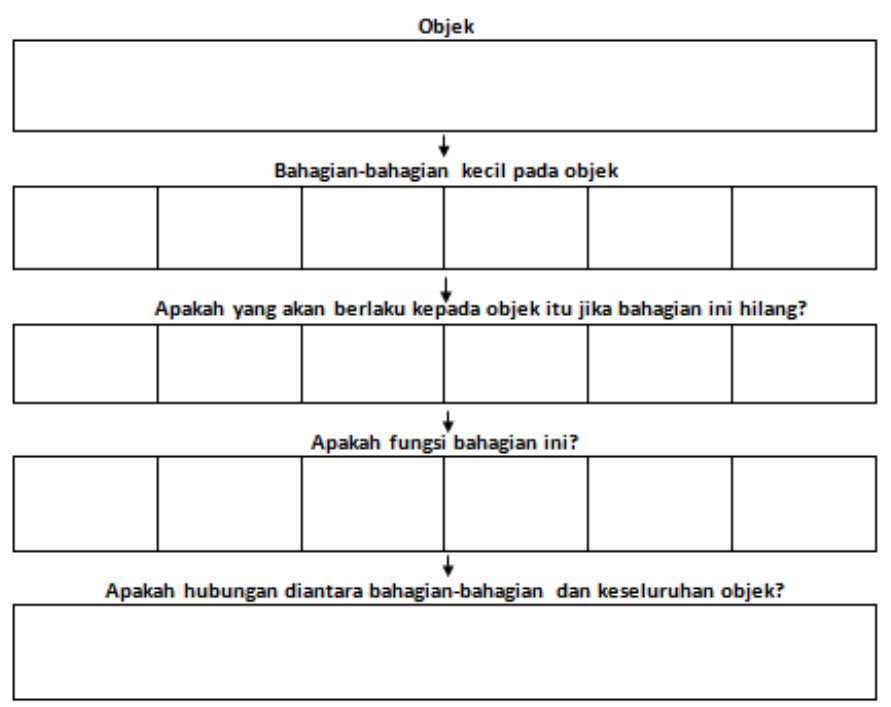

Rajah 1 Peta pemikiran bagi jenis pemikiran hubungan sebahagian keseluruhan (Sumber: NCCT 2011) 
PETA MEMBANDING DAN MEMBEZA

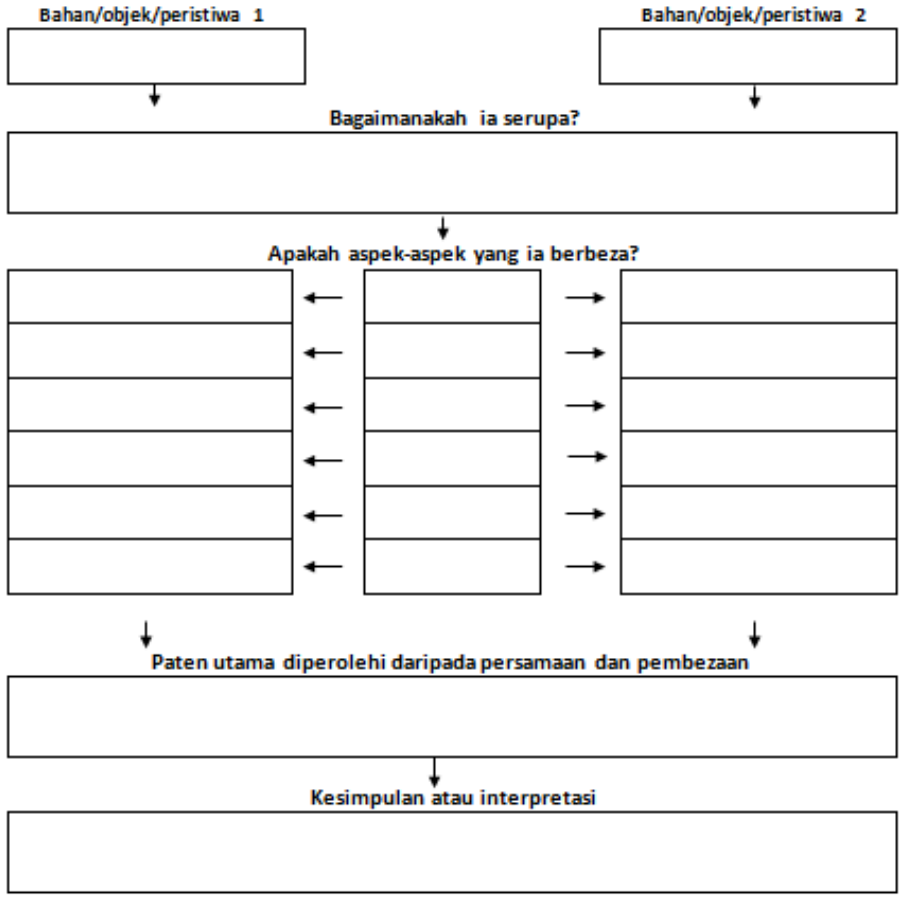

Rajah 2 Peta pemikiran bagi jenis pemikiran membanding dan membeza. Sumber: NCCT 2011

PETA MENGKONSEPSIKAN

Apakah contoh-contoh yang diberi?

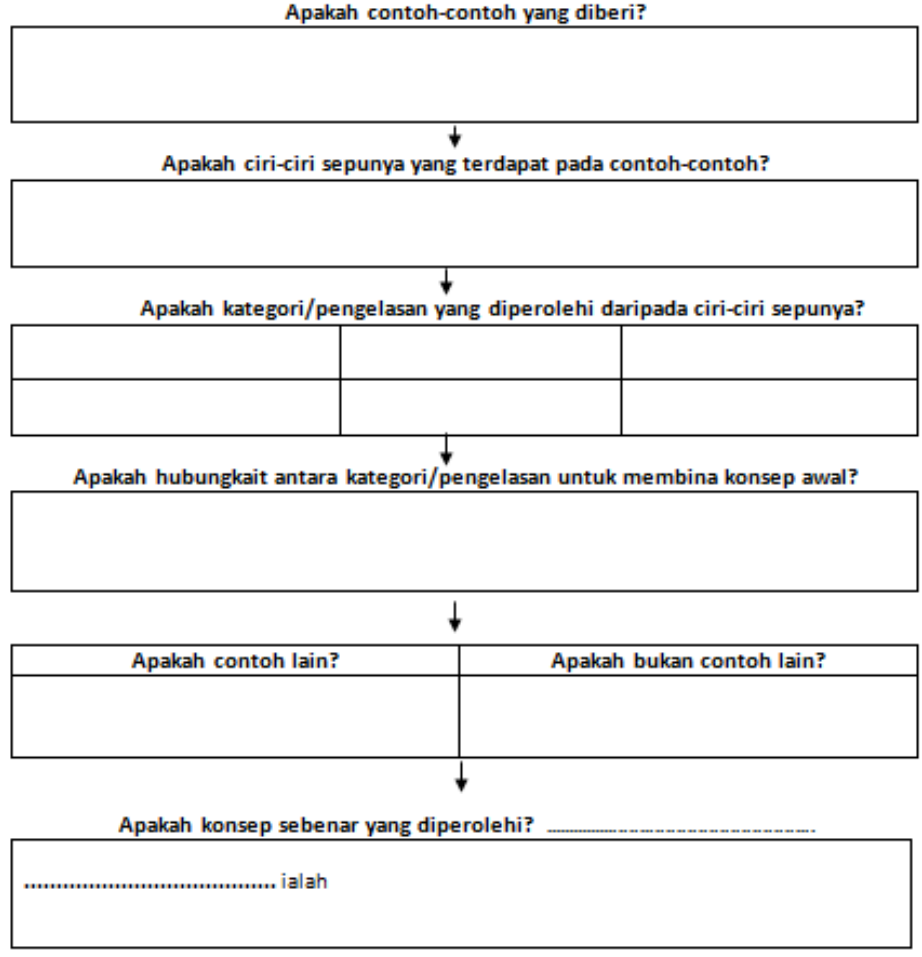

Rajah 3 Peta pemikiran bagi jenis pemikiran mengkonsepsikan 


\section{Objektif dan Soalan Kajian}

Berikut dinyatakan objektif kajian:

Menguji perbezaan pencapaian pelajar dalam kemahiran berfikir dalam tajuk haba sebelum dan selepas rawatan bagi kumpulan rawatan dan kumpulan kawalan.

Berikut dinyatakan soalan kajian yang digunakan dalam kajian ini.

(1) Adakah terdapat perbezaan yang signifikan antara skor praujian haba kritis pelajar dalam kumpulan rawatan dengan skor praujian haba kritis pelajar dalam kumpulan kawalan?

(2) Adakah terdapat perbezaan yang signifikan antara skor praujian dengan pascaujian haba kritis pelajar dalam kumpulan rawatan?

(3) Apakah terdapat perbezaan yang signifikan antara skor praujian dengan pascaujian haba kritis pelajar dalam kumpulan kawalan?

Adakah terdapat perbezaan yang signifikan skor peningkatan antara praujian dengan pascaujian haba kritis pelajar dalam kumpulan rawatan berbanding pelajar dalam kumpulan kawalan?

\subsection{METODOLOGI KAJIAN}

Kajian ini menggunakan reka bentuk kuasi-eksperimental (Chua, 2011) iaitu untuk menguji satu rekabentuk pengajaran iaitu pengajaran berasaskan pemikiran yang dijalankan keatas responden yang tidak diagih secara rawak (Jadual 1). Kajian ini mengambil reka bentuk ujian pra-pasca kumpulan-kumpulan tidak seimbang.

Jadual 1 Reka bentuk kuasi-eksperimen bagi kaedah ujian pra-pasca kumpulan-kumpulan tidak seimbang

\begin{tabular}{lllll}
\hline \multicolumn{1}{c}{ Kumpulan Rawatan } & $\mathrm{N}$ & $\mathrm{U}_{1}$ & $\mathrm{X}$ & $\mathrm{U}_{3}$ \\
\hline \multicolumn{1}{|c|}{ Kumpulan Kawalan } & $\mathrm{N}$ & $\mathrm{U}_{2}$ & & $\mathrm{U}_{4}$ \\
\hline $\mathrm{N}=$ Kumpulan responden tidak seimbang & & & & \\
$\mathrm{X}=$ Rawatan & & & & \\
$\mathrm{U}=$ Pengukuran & & &
\end{tabular}

Untuk meminima atau menyingkir ancaman kerana ciri-ciri yang dimiliki oleh subjek, berikut adalah cadangan Fraenkel dan Wallen (2006) iaitu pemilihan sampel secara rawak, menetapkan sesuatu pembolehubah sebagai pemalar, memasukkan pembolehubah tersebut ke dalam reka bentuk kajian, padanan sampel, menggunakan sampel sebagai kawalan dan menggunakan analisis kovariat. Dalam rekabentuk kajian ini, pengkaji memilih untuk menetapkan sesuatu pembolehubah sebagai pemalar iaitu untuk menyingkirkan kemungkinan kesan pembolehubah dengan mengeluarkannya sebagai kajian. Oleh itu, murid-murid yang sedang dan telah habis tuisyen dalam tajuk haba tidak diambil kira sebagai sampel kajian walaupun mereka berada di dalam kelas dimana kajian ini dijalankan.

Kajian ini hanya melibatkan guru perempuan sahaja sebagai tenaga pengajar. Sekiranya jantina guru tidak seragam, ini boleh menjadi gangguan kepada dapatan kajian kerana (Rosnani Hashim, 2003) menyatakan bahawa terdapat perbezaan persepsi yang signifikan antara guru lelaki dan perempuan iaitu guru lelaki percaya bahawa mereka lebih kompetensi dalam mengajar kemahiran berfikir berbanding guru perempuan.

\section{Pengumpulan Data}

Kajian dijalankan di dua buah sekolah menengah di dalam Daerah Kinta Utara. Setiap sekolah mempunyai dua buah kelas bermakna jumlah kelas yang terlibat dalam kajian ini ialah sebanyak empat buah. Oleh kerana kajian ini hanya melibatkan dua buah sekolah sahaja, maka murid daripada sebuah sekolah menjadi kumpulan rawatan dan murid dari sebuah sekolah lagi menjadi kumplan kawalan. Sampel kajian adalah pelajar Tingkatan Empat yang mengambil mata pelajaran Fizik. Oleh kerana intervensi melibatkan pengajaran di dalam kelas maka pengkaji menggunakan semua murid dalam kelas sedia ada. Sesuai dengan keperluan sekolah dan kajian, pemilihan sampel ialah sampel bertujuan.

Menurut Chua (2009) apabila saiz subjek mencapai 30, data kajian dianggap sebagai bertaburan normal. Dalam kajian ini sampel kumpulan kawalan dan sampel kumpulan rawatan ialah 30 orang. Oleh itu, data kajian dianggap sebagai bertabur secara normal. Fraenkel \& Wallen (2006) untuk kajian eksperimen setiap kumpulan hendaklah mengandungi 30 sampel kajian.

Analisis instrumen ujian haba kritis menggunakan ujian-t untuk pengukuran berpasangan (paired sample t test) dan ujian-t untuk sampel-sampel bebas. Ujian-t untuk pengukuran berpasangan apabila setiap individu dalam sampel diukur dua kali dan kedua-dua data pengukuran digunakan untuk dibuat perbandingan (Chua, 2006). Sampel bebas yang digunakan ialah kumpulan rawatan dan kumpulan kawalan.

Soalan instrumen haba kritis mengandungi tiga jenis kemahiran berfikir iaitu hubungan sebahagian dan keseluruhan; mengkonsepsikan; dan membanding beza. Pemikiran hubungan sebahagian dan keseluruhan; dan membanding beza bertujuan untuk menjelaskan idea, manakala mengkonsepsikan melaksanakan tugas berfikir yang kompleks melalui hasil gabungan beberapa jenis pemikiran (Swartz, et al, 2008). Jadual 2 menunjukkan contoh soalan jenis mengkonsepsikan dalam instrumen haba kritis. 
Jadual 2 Contoh soalan mengkonsepsikan

\begin{tabular}{c} 
Ais krim \\
1 kg ais krim diletakkan atas meja. \\
$\begin{array}{r}\text { Ais krim menyerap haba sebanyak 234,000 J daripada persekitaran dan } \\
\text { akhirnya semua ais krim menjadi cair. } \\
\text { Suhu kekal }-5^{\circ} \mathrm{C} \text { (negatif lima) sepanjang proses ini. }\end{array}$ \\
$\begin{array}{c}\text { Ketul ais batu } \\
\text { Ketul ais batu menyerap haba sebanyak } 336,000 \mathrm{~J} \text { daripada persekitaran } \\
\text { dan akhirnya semua ketul batu menjadi cair. } \\
\text { Suhu kekal } 0{ }^{\circ} \mathrm{C} \text { sepanjang proses ini. }\end{array}$ \\
\\
\hline
\end{tabular}

Situasi ais krim dan situasi ketul ais batu boleh digunakan untuk memahami secara mendalam konsep haba pendam tentu pelakuran.

a Nyatakan empat ciri sepunya situasi ais krim dan situasi ketul ais batu dari Rajah 1 dan Rajah 2.

b Nyatakan empat kategori/kelas berdasarkan ciri sepunya yang terdapat dalam situasi ais krim dan situasi ketul ais batu.

c Kaitkan ketiga-tiga kategori/kelas di atas untuk membentuk pernyataan tentang satu konsep sains.

d Perkaitan yang dibina pada (c) dapat dikonsepsikan sebagai konsep haba pendam tentu pelakuran. Nyatakan konsep haba pendam tentu pelakuran tersebut.

e Nyatakan satu contoh lain dalam kehidupan seharian yang menepati konsep haba pendam pelakuran. Berikan keterangan yang lengkap.

f Nyatakan satu contoh lain dalam kehidupan seharian berkaitan air yang TIDAK melibatkan konsep haba pendam pelakuran. Berikan keterangan yang lengkap.

\subsection{DAPATAN KAJIAN}

Ujian-t bagi sampel-sampel bebas dijalankan untuk membandingkan skor praujian haba kritis bagi kumpulan rawatan dan kumpulan kawalan, rujuk Jadual 3. Keputusan ujian menunjukkan tiada perbezaan yang signifikan dalam skor dimana untuk kumpulan rawatan $(\mathrm{M}=3.57, \mathrm{SD}=2.27)$ dan kumpulan kawalan $(\mathrm{M}=3.90, \mathrm{SD}=2.37)$ syarat; $\mathrm{t}(58)=-0.56, \mathrm{p}=0.58$. Keputusan ini menunjukkan bahawa keduadua kumpulan mempunyai kebolehan yang setara sebelum kajian dalam kebolehan melakukan mengkonsepsikan tajuk haba.

Jadual 3 Keputusan ujian-t bagi sampel-sampel bebas membandingkan keputusan praujian haba kritis bagi kumpulan rawatan dan kumpulan kawalan

\begin{tabular}{|l|c|c|c|c|c|c|}
\hline Kumpulan & $\mathbf{N}$ & $\mathbf{M}$ & SD & df & t & p \\
\hline 1. Rawatan & 30 & 3.57 & 2.27 & 58 & -.56 & $.58^{*}$ \\
\hline 2. Kawalan & 30 & 3.90 & 2.37 & & -.56 & $.58^{*}$ \\
\hline
\end{tabular}

Ujian-t untuk pengukuran berpasangan telah ditadbirkan untuk membandingkan skor praujian haba kritis dengan skor ujian pascaujian haba kritis untuk kumpulan rawatan, rujuk Jadual 4. Keputusan ujian menunjukkan perbezaan yang signifikan dalam skor dimana skor praujian haba kritis $(\mathrm{M}=3.6, \mathrm{SD}=2.27)$ dan skor pascaujian haba kritis $(\mathrm{M}=21.4, \mathrm{SD}=5.30)$ syarat; $\mathrm{t}(29)=3, \mathrm{p}=0.00$. Keputusan ini menunjukkan bahawa teknik penyebatian strategi berfikir mengkonsepsikan mempunyai kesan dalam pencapaian markah ujian haba kritis murid. Didapati bahawa seseorang murid yang diajar melalui teknik penyebatian strategi berfikir mengkonsepsikan menunjukkan peningkatan pencapaian dalam ujian haba kritis.

Jadual 4 Keputusan ujian-t bagi pengukuran berpasangan membandingkan keputusan praujian dan pacsaujian haba kritis bagi kumpulan rawatan

\begin{tabular}{|c|c|c|c|c|c|c|}
\hline Kumpulan Rawatan & N & M & SD & df & t & p \\
\hline 1. Praujian & 30 & 3.57 & 2.27 & 29 & -17.51 & $0.00^{*}$ \\
\hline 2. Pasca ujian & 30 & 21.40 & 5.30 & & & \\
\hline
\end{tabular}

*Aras signifikan pada $\mathrm{p}<0.05$

Ujian-t untuk pengukuran berpasangan telah ditadbirkan untuk membandingkan skor praujian haba kritis dengan skor pascaujian haba kritis untuk kumpulan kawalan, rujuk Jadual 5. Keputusan ujian menunjukkan perbezaan yang signifikan dalam skor dimana skor praujian haba kritis $(\mathrm{M}=3.9, \mathrm{SD}=2.37)$ dan skor pascaujian haba kritis $(\mathrm{M}=9.5, \mathrm{SD}=3.19)$ syarat; $\mathrm{t}(29)=-8.21, \mathrm{p}=0.00$. Keputusan ini menunjukkan 
bahawa pengajaran konvensional mempunyai kesan dalam pencapaian markah ujian haba kritis murid. Didapati bahawa seseorang murid yang belajar dalam pengajaran konvensional masih menunjukkan peningkatan pencapaian dalam ujian haba kritis.

Jadual 5 Keputusan ujian-t bagi pengukuran berpasangan membandingkan keputusan praujian dan pacsaujian haba kritis bagi kumpulan kawalan

\begin{tabular}{|c|c|c|c|c|c|c|}
\hline Kumpulan Kawalan & N & M & SD & df & t & p \\
\hline 1. Praujian & 30 & 3.90 & 2.37 & 29 & -8.21 & $0.00^{*}$ \\
\hline 2. Pasca ujian & 30 & 9.50 & 3.19 & & & \\
\hline *Aras signifikan pada $\mathrm{p}<0.05$
\end{tabular}

Ujian-t bagi sampel-sampel bebas telah dijalankan untuk membandingkan skor peningkatan ujian haba kritis (skor pascaujian - skor praujian) bagi kumpulan rawatan dan kumpulan kawalan, rujuk Jadual 6. Keputusan ujian menunjukkan perbezaan yang signifikan dalam skor dimana skor kumpulan rawatan $(\mathrm{M}=17.83, \mathrm{SP}=5.58)$ dan kumpulan kawalan $(\mathrm{M}=5.60, \mathrm{SP}=3.74)$ syarat; $\mathrm{t}(58)=9.98$, $\mathrm{p}=0.00$. Teknik penyebatian strategi berfikir mempunyai kesan dalam kebolehan melakukan strategi berfikir mengkonsepsikan. Keputusan menunjukkan, murid yang diajar menggunakan strategi berfikir mengkonsepsikan menunjukkan peningkatan skor dalam ujian haba kritis.

Jadual 6 Keputusan ujian-t bagi sampel-sampel bebas membandingkan keputusan peningkatan skor praujian kepada pascaujian haba kritis bagi kumpulan rawatan dan kumpulan kawalan

\begin{tabular}{|l|c|c|c|c|c|c|}
\hline Kumpulan & $\mathbf{N}$ & $\mathbf{M}$ & SD & df & t & p \\
\hline 1. Rawatan & 30 & 17.83 & 5.58 & 58 & 9.98 & $0.00^{*}$ \\
\hline 2. Kawalan & 30 & 5.60 & 3.74 & & 9.98 & $0.00^{*}$ \\
\hline
\end{tabular}

\subsection{PERBINCANGAN}

Pendidik di Malaysia, sering diingatkan kepentingan menerapkan kemahiran berfikir kepada murid-murid semasa pengajaran dan pembelajaran. Semua murid sekolah menengah perlu diajar kemahiran pemikiran kritikal tanpa ditangguh pelaksanaannya, supaya pelajar ketika ini berpeluang untuk bersaing dan berjaya untuk menyumbang dalam pasaran dunia semasa (Carlgren, 2013). Ini sejajar dengan Pelan Pembangunan Pendidikan Malaysia yang mementingkan menerapan elemen $4 C$ dalam pengajaran dan pembelajaran.

Dapatan kajian daripada praujian haba kritis menunjukkan murid-murid yang terlibat dalam kajian mempunyai tahap pengetahuan yang setara terhadap jenis pemikiran seperti hubungan sebahagian keseluruhan, membanding dan membeza; dan mengkonsepsikan. Ini menunjukkan kedua-dua kumpulan murid belum biasa kepada teknik penyebatian kemahiran berfikir dan melakukan jenis-jenis kemahiran berfikir tersebut sebelum ini.

Setelah murid-murid melalui pengajaran menggunakan teknik penyebatian kemahiran berfikir selama empat minggu didapati secara signifikan pencapaian mereka meningkat di dalam pasca ujian haba kritis daripada min skor 3.57 kepada 21.57. Ini menunjukkan bahawa kandungan pelajaran seperti Fizik hendaklah diterapkan ke dalam kemahiran berfikir untuk meningkatkan kedua-dua elemen sekaligus iaitu kemahiran berfikir dan pemahaman kandungan pelajaran. Dapatan ini selari dengan pandangan Nooraini \& Khairul Azmi (2014) iaitu setiap mata pelajaran mestilah menggabungkan elemen berfikir.

Bagi murid-murid yang belajar tajuk haba secara pengajaran konvensional juga secara signifikan mengalami peningkatan markah dalam pascaujian haba kritis daripada min skor 3.90 kepada 9.50. Dalam pengajaran secara konvensional, guru mereka terus memberikan konsep fizik, menerangkan konsep tersebut secara lisan, menggunakan elemen grafik dan video, juga murid membuat soalan latih tubi daripada buku yang dibekalkan oleh pihak sekolah semasa pengajaran. Murid tetap mengalami peningkatan markah kerana mereka telah belajar tajuk haba tetapi tidak belajar jenis-jenis kemahiran berfikir hubungan sebahagian keseluruhan, membanding dan membeza dan mengkonsepsikan.

Peningkatan markah antara pascaujian dan praujian bagi murid yang mengikuti pengajaran teknik penyebatian kemahiran berfikir berbanding pengajaran konvensional adalah signifikan. Oleh itu, teknik penyebatian kemahiran berfikir dapat meningkatkan kemahiran berfikir pelajar dan kefahaman terhadap kandungan pelajaran. Muhammad \& Krishna (t.t.) juga bersetuju bahawa penyebatian kemahiran berfikir (jenis hubungan sebahagian keseluruhan) ke dalam kandungan kursus dapat meningkatkan kemahiran berfikir pelajar. Melaksanakan metakognisi dalam aktiviti sains membantu kepada kejayaan pembelajaran dan mewujudkan sokongan emosi pada tahap tinggi (Ghasempour \& Jahanshahloo, 2012). Berdasarkan dapatan di atas, dicadangkan kepada para guru dalam panitia Sains sekolah untuk menggunakan teknik penyebatian kemahiran berfikir dalam pengajaran tajuk haba sebagai satu alternatif kepada mereka.

\subsection{KESIMPULAN}

Teknik penyebatian kemahiran berfikir murid dapat ditingkatkan dan mempunyai kesan positif terhadap tiga jenis pemikiran iaitu hubungan sebahagian keseluruhan; membanding dan membeza; dan mengkonsepsikan serta dapat meningkatkan kefahaman murid terhadap tajuk haba. Didapati peningkatan skor Ujian Haba Kritis masih belum cukup tinggi oleh itu dicadangkan tempoh masa kajian perlu dipanjangkan lagi iaitu melebihi empat minggu atau melebihi lima kali pengajaran dan pembelajaran.

Rujukan

$21^{\text {st }}$ century skills. (2008). $21^{\text {st }}$ Century Skills, Education \& Competitiveness. Diakses dari www.21stcenturyskills.org. 
Carlgren, T. (2013). Communication, Critikal Thinking, Problem Solving: A Suggested Course For All High School Students in the 21 ${ }^{\text {st }}$ century. Interchange, 44, 6381.

Chua, Y. P. (2006). Kaedah Dan Statistik Penyelidikan. Buku 2. Asas Statistik Penyelidikan. Malaysia: McGraw-Hill (Malaysia) Sdn. Bhd.

Chua, Y. P. (2009). Kaedah dan Statistik Penyelidikan. Buku 4. Statistik Penyelidikan Lanjutan.Ujian Univariat Dan Multivariat. Malaysia: McGraw-Hill (Malaysia) Sdn. Bhd.

Chua, Y. P. (2011). Kaedah Dan Statistik Penyelidikan. Buku 1. Kaedah Penyelidikan. Malaysia: McGraw-Hill (Malaysia) Sdn. Bhd.

Cook, E., Kennedy, E., \& McGuire. (2013). Effect of Teaching Metacognitive Learning Strategies On Performance In General Chemistry Courses. Journal Chemical Education, 90, 961-967.

Costa, A. L., \& Kallick, B. (Ed.). (2008). Learning And Leading With Habits Of Mind. 16 Essential Characteristics For Success. US: ASCD.

Dunlosky, J., \& Metcalfe, J. (2009). Metacognition. USA: Sage Publications.

Flavell, J. H. (1979). Metacognition And Cognitive Monitoring. A New Area Of Cognitive-Developmental Inquiry. American Psychologist, 34 (10), 906-911.

Fraenkel, J. R., \& Wallen, N. E. (2006). How To Design And Evaluate Research In Education. Edisi ke-6. New York, NY: The McGraw-Hill Companies, Inc.

Ghasempour, Z., Md Nor Bakar \& Jahanshahloo, G. R. (2012). Innovation in Teaching And Learning Through Problem Posing Tasks And Metacognitive Strategies. International Journal of Pedagogical Innovations, 1(1), 53-62

Gokhale, A. A. (1995). Collaborative Learning Enhances Critical Thinking. Journal of Technology Education, 7(1). Diakses dari http://scholar.lib.vt.edu/ ejournals/JTE/v7n1/gokhale.jte-v7n1.html

Indrasiene, V., Suboc, V., \& Penkauskiene, D. (September, 2012). Teachers' Attitude Toward The Development Of Critical Thinking During Lessons. Kertas dibentangkan Electronic International Interdisciplinary Conference. Diakses dari htt://www.eiic.cz

Kemahiran berfikir. (2002). Kemahiran Berfikir Dalam Pengajaran Dan Pembelajaran. Pusat Perkembangan Kurikulum. Kuala Lumpur: Kementerian Pendidikan Malaysia.

Kementerian Pendidikan Malaysia (7 September, 2015). Pelan Pembangunan Pendidikan Malaysia 2013-2025. Diakses daripada www.moe.gov.my/v/pelanpembangunan-pendidikan-Malaysia-2013-2025

Kim, Eunsook., \& Pak, S-J. (2002). Student Do Not Overcome Conceptual Difficulties After Solving 1000 Traditional Problems. American Journal Physics, 70(7), 759-765. doi:10.1119/1.1484151

McCollister, K., \& Sayler, M. (2010). Lift the Ceiling: Increase Rigor With Critical Thinking Skills. Gifted Child Today, 33(1), $41-47$.

Membudayakan. (2012). Membudayakan Kemahiran Berfikir. Kementerian Pelajaran Malaysia.

Muhammaad Shafique dan M. R. K. Krishna Rao. (t.t.). Infusing Parts-Whole Relationship Critical Thinking Skill Into Basic Computer Science Education. Diakses daripada http://citeseerx.ist.psu.edu

Nooraini Othman \& Khairul Azmi Mohamad. (2014). Thinking Skill Education And Transformational Progress In Malaysia. International Education Studies, 7(4):27-32.

Nurulhuda Abd Rahman \& Md Nasir Ibrahim. (Eds.). (2013). Pemikiran kritis Dan Kreatif: Konsep, Pendekatan Pengajaran Dan Aplikasi Dalam Pengajaran Dan Pembelajaran. Malaysia: Universiti Pendidikan Sultan Idris.

Redish, E. F. (1994). Implications of Cognitive Studies For Teaching Physics. American Journal Physics, 62(9), 796-803.

Rosnani Hashim. (2003) Malaysian Teachers' Attitudes, Competency And Practices In The Teaching Of Thinking. Intellectual Discourse, 11(1), 27-50.

Sandall, L., Mamo, M., Speth, C., Lee, D., \& Kettler, T. (2014). Student Perception Of Metacognitive Activities In Entry-Level Science Courses. Natural Sciences Education, 43, 25-32. doi:10.4195/nse2013.06.0021.

Sarimah Binti Kamrin dan Shaharom bin Noordin. (2008). Tahap Penguasaan Kemahiran Berfikir Kritis Pelajar Sains Tingkatan Empat. Jurnal Pendidikan Universiti Teknologi Malaysia. 13, 58-72.

Schraw, G., Crippen, K. J., \& Hartley, K. (2006). Promoting Self-Regulation In Science Education:Metacognition As Part Of A Broader Perspective On Learning. Research in Science Education,36, 111-139. doi:10.1007/s11165-005-3917-8.

Sukatan pelajaran. (2001). Sukatan Pelajaran Kurikulum Bersepadu Sekolah Menengah. Fizik. Pusat Perkembangan Kurikulum. Ampang/Hulu Kelang, Selangor: Kementerian Pendidikan Malaysia.

Swartz, R. J., Costa, A. L., Beyer, B. K. Reagan, R., \& Kallick, B. (2008). Thinking-Based Learning. Promoting Quality Student Achievement In The 21 ${ }^{\text {st }}$ Century. New York dan London: Teachers College Press.

Swartz, R. J., \& McGuinness, C. (2014). Developing and Assessing Thinking Skills. The International Baccalaureate Project 2014 (Report No. Part 1). Diakses dari www.ibo.org/globalassets/publications/ib-research/continuum/student-thinking-skills-report-part-1.pdf

Swartz, R. J., \& Parks, S. (1994). Infusing The Teaching Of Critical And Creative Thinking Into Elementary Instruction. Pacific Grove, CA: Critical Thinking Press.

Venville, G., \& Oliver, M. (2015). The Impact Of A Cognitive Acceleration Programme In Science On Students In An Academically Selective High School. Thinking Skills and creativity, $15,48-60$.

Yildirim, S., \& Ersozlu, Z. N. (2013). The Relationship Between Students' Metacognitive Awareness And Their Solutions To Similar Types Of Mathematical Problems. Eurasia Journal of Mathematics, Science \& Technology Education, 9(4), 411-415. doi:10.12973/eurasia.2013.946a. 